\title{
ACETYLATION STUDIES IN HUMAN SUBJECTS WITH METABOLIC DISORDERS ${ }^{1}$
}

\author{
BY HERBERT GERSHBERG AND W. JAMES KUHL, JR. \\ (From the Department of Medicine, New York University College of Medicine, and the \\ Third [New York University] Medical Division, Bellevue Hospital, New York City)
}

(Submitted for publication July 28, 1950; accepted, September 26, 1950)

The role of acetate as an intermediate metabolite has been the subject of considerable study (1). Its importance as a common pathway in the metabolism of carbohydrate, protein and fat has been established, and it has been implicated in the synthesis of cholesterol (2), porphyrins (3), fatty acids (4) and indirectly glucose (5).

Acetate is rapidly metabolized and its measurement is a difficult procedure. Information concerning its behaviour has been derived from experiments involving the acetylation of the aromatic amines para-aminobenzoic acid (PABA) and sulfanilamide. This reaction has been shown by Lipmann to require, in addition to available acetate, coenzyme A (6), which contains pantothenic acid, and adenosine triphosphate (7). Although there have been many in vivo and in vitro studies in animals there are few reports of studies of this reaction in human subjects. In this study we have used the acetylation of PABA and sulfadiazine in normal individuals and in persons with metabolic disorders as a means of investigating acetate metabolism in human subjects.

\section{PROCEDURE}

The subjects were normal males and females, including several patients convalescing from mild infections; patients with cirrhosis of the liver, hyperthyroidism and hypothyroidism, leukemia, sprue, diabetes mellitus, rheumatoid arthritis, and adrenal insufficiency. The hospital patients were maintained on the regular hospital diet which consisted of approximately $250-300$ gms. of carbohydrate, $70 \mathrm{gms}$. of protein, 85 gms. of fat, supplying about 2,300 Calories a day. Clinic patients were allowed to eat their usual diets. Patients with diabetes mellitus were attending the outpatient clinic and continued on their diabetic diets.

PABA was administered orally in $100 \mathrm{mgm}$. tablets at 7 p.m., and the urine collected under toluene for the next 12 hours, during which period food intake was not restricted. Free and total PABA was determined on an

1 This research was aided by a grant from The Roche Anniversary Foundation. aliquot of the urine by the method of Bratton and Marshall (8) and the amount acetylated calculated as the difference between the two. Results are expressed as the per cent acetylated of the amount excreted in the urine. PABA is rapidly absorbed and recoveries ranged from $80-90 \%$. If the recovery was less than $65 \%$ the experiment was discarded, and if serial experiments on the same individual differed by more than $15 \%$ they were not used. In other studies PABA was injected intravenously as a $10 \%$ solution of the sodium salt in distilled water. It was injected after breakfast, $5 \mathrm{mls}$. in two to three minutes, and urine samples were collected for the subsequent four or six and 12 hour periods. Sulfadiazine was injected intravenously as a $10 \%$ solution of the sodium salt in distilled water, and hourly urine specimens were collected under toluene by an indwelling catheter.

Other chemical determinations done were: serum cholesterol by a modification of the method of Schoenheimer and Sperry (9), serum proteins by the method of Howe (10), and hippuric acid was measured by Quick's technique (11) in urine collected for four hours following the ingestion of $6 \mathrm{gms}$. of sodium benzoate by mouth.

Pantothenic acid was administered orally in the form of calcium pantothenate or the alcohol derivative of pantothenic acid, 3-12 gms. daily, in three divided doses. Sodium acetate was given orally as a $40 \%$ solution in water, $30 \mathrm{mls}$. three times daily, making a daily dose of 36 gms.

\section{Normal Subjects}

The capacity to acetylate orally administered PABA was studied in ten normal adults. Varying doses of PABA were tested, and it was observed that the per cent acetylated decreased as the size of the dose increased. In Figure 1 most of the points represent the average of several experiments on the same individual. The slope of the curve is similar to that obtained in adult rats (12), although on a body weight basis acetylation in humans was greater. Five hundred mgm. of PABA were selected as a standard dose for most of the experiments in this study, since there appeared to be a greater change in the slope of the curve at this point. With relatively larger test doses in rats, differences in acetylation due to nutritional deficiencies tend to disappear (13). 


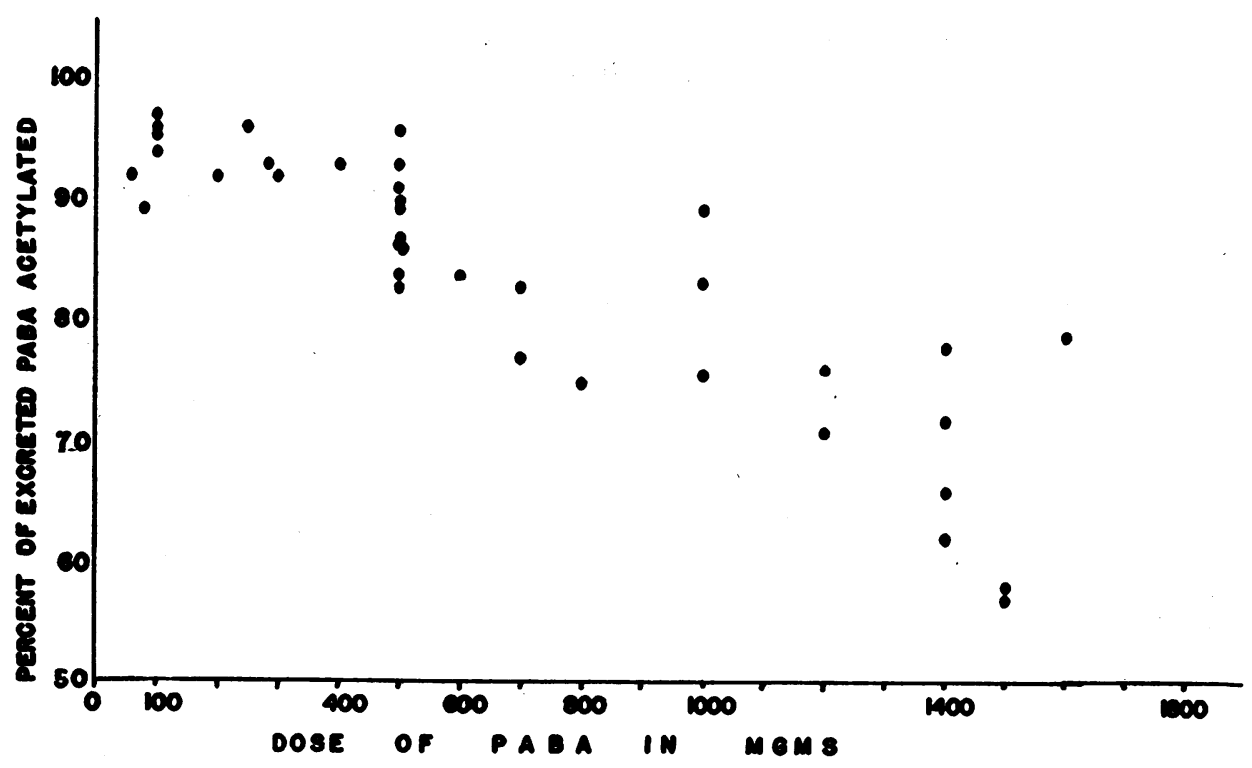

Fig. 1. The Relation of the Dose of PABA Administered to the Per Cent of the ACETYLATEd Form EXCRETED

No correlation was observed between the body weight or the urinary volume and the ability to acetylate as is shown in Figure 2 . In six normal individuals acetylation of the same dose of PABA was determined at intervals over a six month period. Except for one instance the variation, using a large or small dose, was not great. Four of these subjects were given 3 gms. of calcium pantothenate a day for periods up to 22 days. This did not alter their capacity to acetylate either a $500 \mathrm{mgm}$. or a $1,400 \mathrm{mgm}$. dose of PABA.
Measurements on three of the subjects are given in Table I.

When $500 \mathrm{mgm}$. PABA were injected intravenously, $73 \%$ was acetylated in the 12 hour urine specimen (Table II). This is significantly less than the acetylation of the same dose after oral administration ( $88 \%$ ). It was observed that the per cent acetylated increased the longer the elapsed time after administration, being greater in the six to 12 hour urine samples.

- Females - males

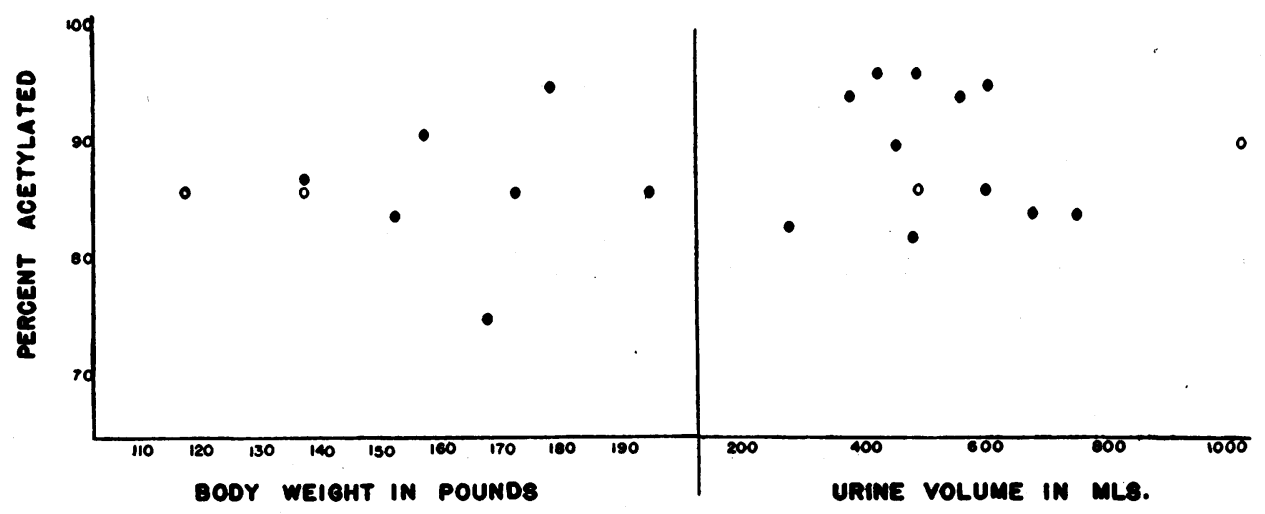

Fig. 2. The Relation of the Acetylation of 500 mgM. of PABA to the Body Weight and Urine Volume in Normal Adult Males and Females 
TABLE I

Acetylation of PABA in normal males before and after large doses of pantothenate*

\begin{tabular}{|c|c|c|c|c|}
\hline Subject & Date & Treatment & $\begin{array}{c}\text { Dose } \\
\text { PABA }\end{array}$ & $\begin{array}{l}\text { Per cent } \\
\text { acetylated }\end{array}$ \\
\hline $\mathrm{HL}$ & \begin{tabular}{|r|}
$5 / 16 / 49$ \\
$5 / 24 / 49$ \\
$12 / 13 / 49$ \\
$9 / 20 / 49$ \\
$11 / 15 / 49$ \\
$12 / 1 / 49$
\end{tabular} & $\begin{array}{l}\text { None } \\
\text { None } \\
\text { Pantoth. } 22 \text { days } \\
\text { None } \\
\text { None } \\
\text { Pantoth. } 10 \text { days }\end{array}$ & $\begin{array}{r}m g m . \\
1,400 \\
1,400 \\
1,400 \\
500 \\
500 \\
500\end{array}$ & $\begin{array}{l}66 \\
62 \\
62 \\
91 \\
90 \\
95\end{array}$ \\
\hline HA & $\begin{array}{r}5 / 16 / 49 \\
6 / 1 / 49 \\
12 / 15 / 49 \\
9 / 8 / 49 \\
11 / 15 / 49 \\
11 / 21 / 49 \\
12 / 1 / 49\end{array}$ & $\begin{array}{l}\text { None } \\
\text { None } \\
\text { Pantoth. } 22 \text { days } \\
\text { None } \\
\text { None } \\
\text { None } \\
\text { Pantoth. } 10 \text { days }\end{array}$ & $\begin{array}{r}1,400 \\
1,400 \\
1,400 \\
500 \\
500 \\
500 \\
500\end{array}$ & $\begin{array}{l}72 \\
78 \\
77 \\
84 \\
94 \\
83 \\
95\end{array}$ \\
\hline GE & $\begin{array}{r}5 / 26 / 49 \\
12 / 16 / 49 \\
11 / 15 / 49 \\
11 / 23 / 49 \\
12 / 4 / 49\end{array}$ & $\begin{array}{l}\text { None } \\
\text { Pantoth. } 21 \text { days } \\
\text { None } \\
\text { None } \\
\text { Pantoth. } 9 \text { days }\end{array}$ & $\begin{array}{r}1,500 \\
1,500 \\
500 \\
500 \\
500\end{array}$ & $\begin{array}{l}58 \\
54 \\
86 \\
96 \\
82\end{array}$ \\
\hline
\end{tabular}

* Three gms. daily of pantothenate given in three divided doses.

\section{Cirrhosis of the Liver}

Seven patients with severe cirrhosis of the liver and marked ascites were given various doses of PABA. The data on acetylation as well as the blood chemistries done at the same time as the acetylation studies are shown in Table III. $\mathrm{Pa}$ tients VA and GR had had no previous medication and gave a history of an inadequate diet for many months before hospitalization. The other patients had received vitamins for periods varying from one to 12 weeks before the studies were done. All

TABLE II

Acetylation of $500 \mathrm{mgm}$. of intravenously administered $P A B A$ in normal subjects

\begin{tabular}{c|c|c|c|c|c|c}
\hline \multirow{2}{*}{ Subject } & \multicolumn{3}{|c|}{ Per cent recovery } & \multicolumn{3}{c}{ Per cent acetylated } \\
\cline { 2 - 7 } & $0-4 \mathrm{hr}$. & $4-12 \mathrm{hr}$. & $\begin{array}{c}\text { Total } \\
12 \mathrm{hr} .\end{array}$ & $0-4 \mathrm{hr}$. & $4-12 \mathrm{hr}$. & $\begin{array}{c}\text { Total } \\
12 \mathrm{hr} .\end{array}$ \\
\cline { 2 - 7 } CO & 54 & 12 & 66 & 75 & 98 & 80 \\
WI & 62 & 6 & 68 & 63 & 90 & 66 \\
VE & 67 & - & - & 62 & - & - \\
\hline & $0-6 \mathrm{hr}$. & $6-12 \mathrm{hr}$. & & $0-6 \mathrm{hr}$. & $6-12 \mathrm{hr}$. & \\
\hline WO & 72 & 5 & 77 & 74 & 88 & 75 \\
ST & 72 & 4 & 76 & 69 & 83 & 70 \\
SA & 55 & 8 & 63 & 72 & 91 & 75 \\
\hline
\end{tabular}

Mean \pm standard error $=73 \pm 2.4$.
TABLE III

Acetylation in patients with cirrhosis of the liver

\begin{tabular}{l|c|c|c|c|c|c|c}
\hline \hline Patient & $\begin{array}{c}\text { Dose } \\
\text { PABA }\end{array}$ & $\begin{array}{c}\text { Per cent } \\
\text { acetylated }\end{array}$ & $\begin{array}{c}\text { Average } \\
\text { normal } \\
\text { per cent } \\
\text { acetylated* }\end{array}$ & \multicolumn{2}{|c|}{$\begin{array}{c}\text { Serum } \\
\text { gms. per cent }\end{array}$} & \multicolumn{2}{|c|}{$\begin{array}{c}\text { Serum } \\
\text { cholesterol }\end{array}$} \\
\cline { 5 - 7 } & mgm. & & & & Total & Free \\
BE & 2,000 & 85 & $<68$ & & & 95 & 43 \\
WA & 1,500 & 82 & 68 & & & & alb. \\
LO & 1,400 & 91 & 69 & 2.3 & 3.12 & 154 & 36 \\
VA & 1,400 & 79 & 69 & 2.14 & 3.99 & 101 & 43 \\
GR & 1,100 & 79 & 75 & 1.65 & 3.61 & 105 & 32 \\
VA & 700 & 82 & 80 & 2.14 & 3.99 & 101 & 43 \\
RA & 500 & 82 & 88 & 1.95 & 4.13 & 140 & 37 \\
MO & 500 & 90 & 88 & 1.87 & 4.82 & 151 & 34 \\
\hline
\end{tabular}

* Calculated from values in normal subjects.

the patients had a normal capacity to acetylate in spite of the presence of severe liver disease.

\section{Diabetes Mellitus}

Seven diabetics requiring from $20-45$ units of insulin daily were studied. The dose of insulin was regulated so as to permit a 2 to 3 plus glycosuria during the period of the test. Insulin was omitted the evening of the administration of the PABA and also the following morning. All seven diabetics were found to acetylate the standard dose normally (Table IV).

\section{Rheumatoid Arthritis}

Eight patients with active rheumatoid arthritis were studied and found to acetylate PABA as well as normal individuals (Table IV). Acetylation was also measured after the intravenous injection of sulfadiazine, and was at approximately the same level as that found in normal subjects (Figure 3 ). During the first five hours the percentage of the recovered sulfadiazine that was acetylated increased progressively, and was greatest in the five to 12 hour specimen, which was similar to the results obtained after the intravenous administra-

TABLE IV

Acetylation of $500 \mathrm{mgm}$. orally administered $P A B A$ in patients with diabetes mellitus, rheumatoid arthritis, leukemia and sprue

\begin{tabular}{lcl}
\multicolumn{1}{c}{ Disease } & No. of subjects & $\begin{array}{c}\text { Per cent acetylated } \\
\text { Mean } \pm \text { std. error }\end{array}$ \\
Normal & 9 & $88 \pm 1.9$ \\
Diabetes mellitus & 7 & $90 \pm 2.4$ \\
Rheum. arthritis & 8 & $85 \pm 1.2$ \\
Leukemia & 5 & $90 \pm 2.4$ \\
Sprue & 3 & 88 (range 76-95)
\end{tabular}




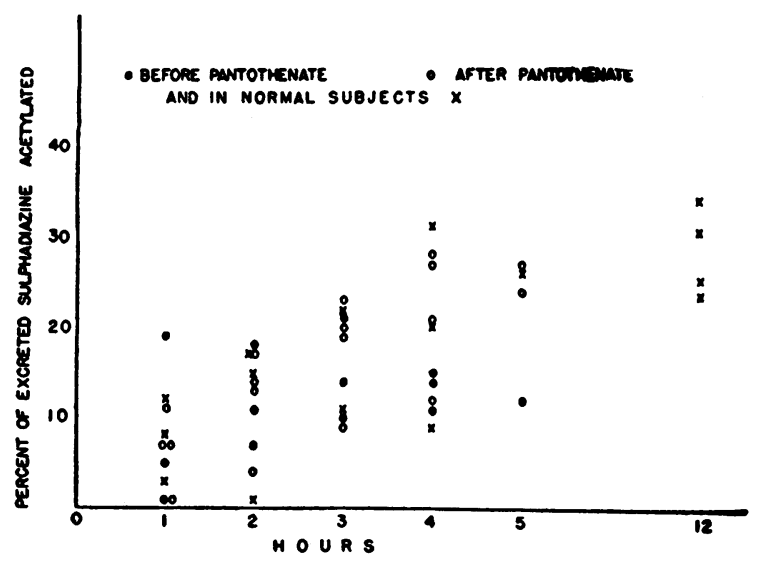

Fig. 3. The Per Cent of Excreted Sulfadiazine Acetylated Per Hour in Patients with Rheumatoid Arthritis Before and After Receiving Calcium Pantothenate AND IN Normal Subjects

tion of PABA. Ten gms. of pantothenic acid orally daily for periods of from 12 to 104 days had no effect on the acetylation of the standard dose of PABA or sulfadiazine.

Acetylation of the standard dose of PABA was determined in two patients with rheumatoid arthritis before and during therapy with ACTH

TABLE V

Acetylation of $P A B A$ in patients with adrenal insufficiency

\begin{tabular}{|c|c|c|c|}
\hline Patient & Therapy & PABA & $\begin{array}{l}\text { Per cent } \\
\text { acety- } \\
\text { lated }\end{array}$ \\
\hline MA & $\mathrm{DCA}$ and $\mathrm{NaCl}$ & $\begin{array}{r}m g m . \\
500\end{array}$ & 77 \\
\hline Male, 110 lbs. & $\begin{array}{l}\text { Calcium pantothenate plus } \\
\text { cortical extract daily for } \\
26 \text { days }\end{array}$ & 500 & 78 \\
\hline \multirow[t]{3}{*}{$\begin{array}{l}\text { Addison's } \\
\text { disease }\end{array}$} & $\mathrm{NaCl}$ alone & 500 & 69 \\
\hline & None for 6 days & 500 & 66 \\
\hline & $\begin{array}{l}\text { Adrenal cortical extract } \\
\text { and saline infusions daily } \\
\text { for } 7 \text { days } \\
\qquad- \text { and - } \\
\text { for } 20 \text { days }\end{array}$ & 500 & 78 \\
\hline \multicolumn{4}{|l|}{ HI } \\
\hline Male, 195 lbs. & None & 1,700 & 78 \\
\hline \multirow[t]{2}{*}{$\begin{array}{l}\text { Chromophobe } \\
\text { adenoma }\end{array}$} & $\mathrm{DCA}$ and $\mathrm{NaCl}$ & & \\
\hline & $\begin{array}{l}\text { Adrenal cortical extract, } \\
\text { calcium pantothenate for } \\
2 \text { months }\end{array}$ & 1,700 & 70 \\
\hline
\end{tabular}

(100 mgm. daily for seven days) - a dose that produced a beneficial therapeutic effect. There was a decrease of $7 \%$ in the per cent acetylated in one individual, and a rise of $3 \%$ in the other.

\section{Adrenal Insufficiency}

Two patients with adrenal insufficiency were studied while receiving different therapeutic agents. One of these was a patient with Addison's disease who was. studied while he was receiving DCA and salt, while receiving pantothenic acid, and during an adrenal crisis (Table V). During the crisis there was a slight decrease in his ability to acetylate, whereas during treatment

\section{TABLE VI}

Acetylation of $500 \mathrm{mgm}$. PABA in thyroid disease

$\begin{array}{lcc}\text { Patient } & \begin{array}{c}\text { Basal metabolic rate } \\ \text { per cent }\end{array} & \text { Per cent acetylated } \\ \text { RA } & -20 & 87 \\ \text { CR } & -19 & 83 \\ \text { ST } & \text { Myxedematous } & 89 \\ \text { ME } & -15 & 91 \\ \text { SM } & -32 & 91 \\ \text { FR } & -16 & 88 \\ & & \text { Mean } \pm \text { st'd error }=88 \pm 1.2 \\ \text { QU } & +38 & 80 \\ \text { ME } & +44 & 80 \\ \text { MI } & +45 & 76 \\ \text { WE } & +45 & 74 \\ \text { RO } & +45 & 83 \\ \text { WO } & +61 & 45 \\ \text { KO } & +62 & 57 \\ \text { WA } & +80 & \text { Mean } \pm \text { st'd error }=70 \pm 4.8\end{array}$

$P$ value $<0.01$ indicating a significant difference between hypothyroids and hyperthyroids.

Correlation coefficient ( $r$ ) between BMR and per cent acetylation in hyperthyroids is -0.511 .

with cortical extract and saline infusions his capacity to acetylate improved. In general his ability to acetylate was below that of normal individuals. The other subject was a patient with a chromophobe adenoma of the pituitary who was studied while exhibiting symptoms of adrenal insufficiency (serum sodium 120 meq. per L). He acetylated within normal limits at the dosage given-1,700 mgm. PABA.

\section{Thyroid Disease}

Acetylation was studied in 13 patients with untreated hyperthyroidism and in seven patients with hypothyroidism, using different doses of PABA. 
All medications were discontinued in the latter group for at least seven days prior to the study, by which time the patients had some symptoms of hypothyroidism. Acetylation was found to be within the normal range in the patients with hypothyroidism, while the patients with hyperthyroidism showed a decreased capacity to acetylate. This relationship held true with both the large $(1,300 \mathrm{mgm}$.$) or small (500 \mathrm{mgm}$.) dose of PABA. The data on the patients tested with the $500 \mathrm{mgm}$. dose are shown in Table VI. In general the higher the initial BMR in hyperthyroidism, the less the capacity to acetylate $(r=$ -0.511 ). Acetylation was lowest in those patients who had had the disease for a long time and who had lost weight.

In six of the patients with hyperthyroidism the capacity to acetylate was measured during the course of treatment with propylthiouracil and iodine. The patients were hospitalized during this period. The basal metabolism, acetylation studies and blood studies were done on admission, and repeated at approximately weekly intervals as treatment progressed. The determinations were also repeated following thyroidectomy. The results on five of these patients are shown in Figure 4. As the thyrotoxicosis subsided the acetylation increased in three of the patients before oper- ation. In MI acetylation increased three weeks after operation. In MC, tested with $1000 \mathrm{mgm}$., there was no change two weeks post-operatively. The serum cholesterol level, determined on patients $\mathrm{KO}$ and $\mathrm{ME}$, also increased at approximately the same time as did the acetylation of PABA.

Two possible mechanisms were examined in an effort to determine the cause of the decreased acetylation in patients with hyperthyroidism.

A. On the premise that the decrease in acetylation in hyperthyroidism might be due to a diminution of available acetate due to its rapid utilization, and that this might also reflect itself in a low serum cholesterol, two patients with severe hyperthyroidism were kept at bed rest for two weeks with no medication. After control studies, 36 gms. of sodium acetate were given daily by mouth in the form of a $40 \%$ solution. Serum cholesterol and acetylation were determined at frequent intervals. In both cases there was a significant rise in acetylation (Table VII). There was, however, no comparable increase in serum cholesterol over the period studied. Acetylation studies done immediately after the cessation of acetate were unsatisfactory due to poor recovery. Patient RO became more severely toxic during this period, which might explain the fall in serum cholesterol.

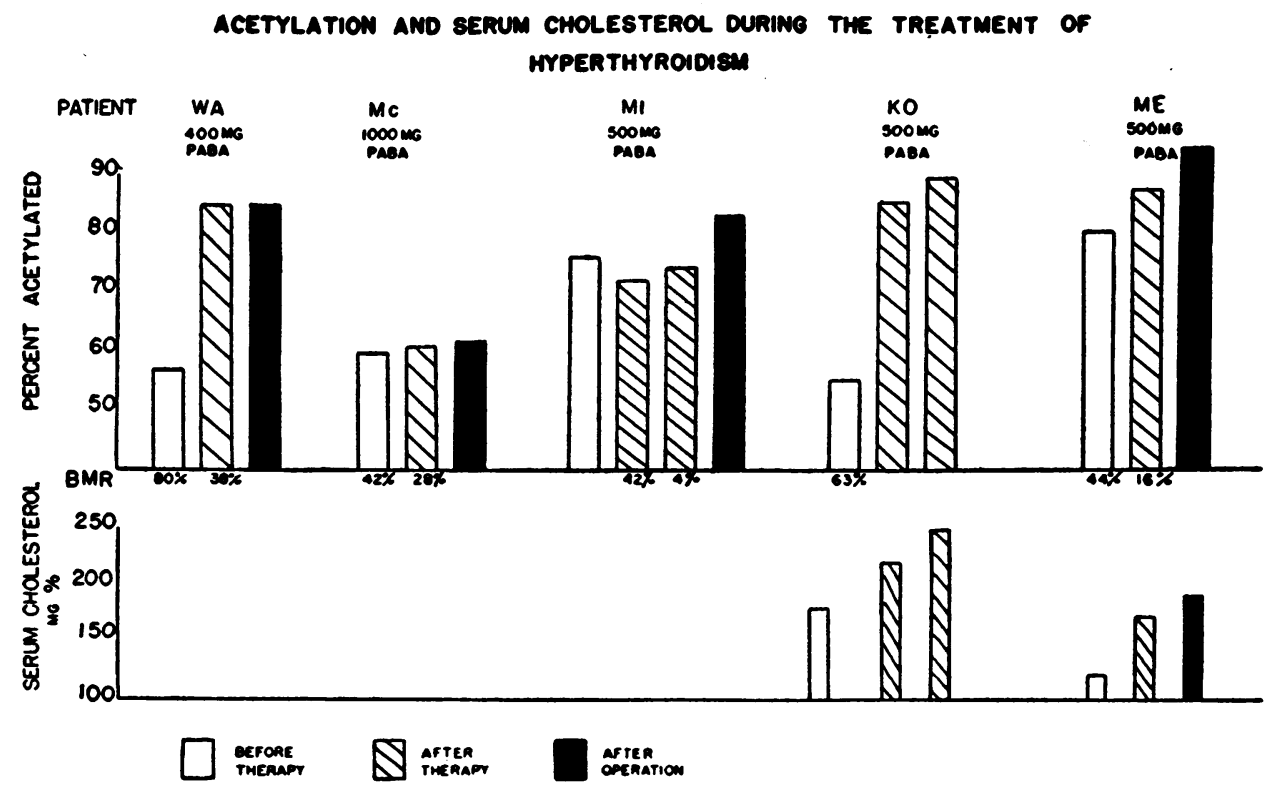

Fig. 4. The Acetylation and Serum Cholesterol in Patients with Hyperthyroidism Before Treatment, During Treatment with Propylthiouracil and Following Operation 
TABLE VII

Effect of sodium acetate on the acetylation of $500 \mathrm{mgm}$. of $P A B A$ and on the serum levels of cholesterol in two patients with hyperthyroidism

\begin{tabular}{|c|c|c|c|c|c|c|}
\hline \multirow{2}{*}{ Patient } & \multirow{2}{*}{$\begin{array}{c}\text { Time } \\
\text { interval } \\
\text { in days }\end{array}$} & \multirow{2}{*}{ Treatment } & \multirow{2}{*}{ BMR } & \multirow{2}{*}{$\begin{array}{c}\text { Per } \\
\text { cent } \\
\text { acety- } \\
\text { lated }\end{array}$} & \multicolumn{2}{|c|}{$\begin{array}{c}\text { Serum } \\
\text { cholesterol }\end{array}$} \\
\hline & & & & & Total & Free \\
\hline $\begin{array}{l}\text { RO } \\
\text { Male } \\
52 \text { yrs. }\end{array}$ & $\begin{array}{c}0 \\
1 \text { day } \\
5 \text { days } \\
8 \text { days } \\
12 \text { days } \\
15 \text { days } \\
19 \text { days } \\
23 \text { days } \\
30 \text { days }\end{array}$ & $\begin{array}{l}\text { None } \\
\text { None } \\
\text { Na acetate, } 36 \mathrm{gms} \text {. } \\
\text { daily } \\
\text { Na acetate, } 36 \mathrm{gms} \text {. } \\
\text { daily } \\
\text { Na acetate, } 36 \mathrm{gms} \text {. } \\
\text { daily } \\
\text { Na acetate, } 36 \mathrm{gms} \text {. } \\
\text { daily. } \\
\text { Propylthiouracil. } \\
200 \text { mgm. daily } \\
\text { Na acetate cut } \\
\text { Propylthiouracil, } \\
200 \text { mgm. daily } \\
\text { Propylthiouracil, } \\
200 \text { mgm. daily }\end{array}$ & $\begin{array}{l}+37 \% \\
+61 \% \\
+52 \%\end{array}$ & $\begin{array}{l}63 \\
86\end{array}$ & $\begin{array}{c}m g m . \\
180 \\
186 \\
180 \\
156 \\
139 \\
137 \\
143 \\
148 \\
176\end{array}$ & $\begin{array}{c}\text { per } \\
\text { cent } \\
46 \\
54 \\
52 \\
48 \\
22 \\
26 \\
27 \\
\\
25 \\
48\end{array}$ \\
\hline $\begin{array}{l}\text { KO } \\
\text { female } \\
42 \text { yrs. }\end{array}$ & \begin{tabular}{|c}
0 \\
4 days \\
8 days \\
9 days \\
10 days \\
12 days \\
13 days \\
14 days \\
19 days \\
25 days \\
34 days
\end{tabular} & $\begin{array}{l}\text { None } \\
\text { Na acetate, } 36 \mathrm{gms} . \\
\text { daily } \\
\text { Na acetate, } 36 \mathrm{gms} . \\
\text { daily } \\
\text { Na acetate, } 36 \mathrm{gms} . \\
\text { daily } \\
\text { Na acetate, } 36 \mathrm{gms} . \\
\text { daily } \\
\begin{array}{l}\text { Propylthiouracil } \\
\text { begun } 200 \mathrm{mgm}\end{array} \\
\text { daily } \\
\text { Na acetate cut } \\
\text { Propylthiouracil } \\
\text { Propylthiouracil }\end{array}$ & $+94 \%$ & $\begin{array}{l}78 \\
82 \\
85 \\
89\end{array}$ & $\begin{array}{l}180 \\
180 \\
186\end{array}$ & $\begin{array}{l}29 \\
49 \\
48\end{array}$ \\
\hline
\end{tabular}

KO showed a normal acetylation in subsequent studies after the cessation of acetate, but by this time antithyroid therapy had been instituted and the hyperthyroidism had subsided appreciably.

B. To test the premise that the decreased acetylation in hyperthyroidism is due to a low coenzyme A concentration caused by increased requirement for pantothenic acid (14) one hyperthyroid patient GU was given 9 gms. of pantothenic acid daily for 14 days. This resulted in a $6 \%$ increase in the acetylation of $1 \mathrm{gm}$. of sulfadiazine collected over a five hour period (from $16 \%$ to $22 \%$ ) which is not considered significant with our method. Patients KO and RO excreted, on the basis of 12 hour urine studies, 7.8 and $2.4 \mathrm{mgm}$. respectively of pantothenic acid daily at the height of their thyrotoxicosis. These values are within the normal range and also indicate that a coenzyme $\mathrm{A}$ deficiency is probably not involved.

The capacity to form hippuric acid by conjugation on the carboxyl group of benzoic acid and the capacity to acetylate PABA were studied in the same patients at four day intervals (Table VIII). One patient with hyperthyroidism acetylated poorly, but formed a normal amount of hippuric acid. Two patients with liver disease and normal renal function acetylated normally but formed subnormal amounts of hippuric acid.

\section{Leukemia}

Five patients with leukemia were studied since elevation of the basal metabolic rate occurs in this disease. Three of these patients had chronic myelogenous leukemia, one had acute lymphatic leukemia, and the other acute myeloblastic leukemia. All five acetylated normally (Table IV).

TABLE VIII

The excretion of hippuric acid and the acetylation 0 $500 \mathrm{mgm}$. PABA in one hyperthyroid and two patients with cirrhosis of the liver

\begin{tabular}{c|c|c|c|c}
\hline \hline Patient & Disease & $\begin{array}{c}4 \text { hr. } \\
\text { urine } \\
\text { vol. }\end{array}$ & $\begin{array}{c}\text { Hippuric } \\
\text { acid } \\
\text { excreted* }\end{array}$ & $\begin{array}{c}\text { Per cent } \\
\text { acetylated }\end{array}$ \\
\hline & mls. & gms. & \\
MI & Hyperthyroidism & 402 & 4.10 & 73 \\
RA & Cirrhosis of liver & 525 & 2.07 & 82 \\
GR & Infectious hepatitis & 470 & 1.94 & 88 \\
\hline
\end{tabular}

* As grams of benzoic acid

\section{DISCUSSION ${ }^{\circ}$}

The acetylation studies in normal individuals and in patients with metabolic disturbances demonstrate the relative constancy of this reaction in a given subject over a long period.

The observation that acetylation is normal in patients with severe liver disease might indicate that this function of the liver is maintained long after other functions are impaired, but more likely indicates that in humans, acetylation is not confined solely to liver tissue. However, even in rats, other tissues participate in reactions involving acetic acid. The conversion of acetate to cholesterol takes place in the adrenal cortex (15), kidney, testis, small intestine and skin (16), as well as in the liver (17). Moreover, coenzyme A, a requisite for acetylation, is present in the adrenal cortex, kidney, brain, heart and testis (18).

The normal acetylation in patients with diabetes mellitus is in contrast with the findings in alloxan diabetic rats (12). The discrepancy might be due to the continued effect of insulin in the patients, 
since in rats the effect of insulin in increasing acetylation lasted for three weeks after it was discontinued. However, considering the severity of the clinical diabetes the observation is probably attributable to the difference between acute alloxan diabetes and the spontaneous human disease.

The consistent decrease in acetylation in patients with hyperthyroidism might be a reflection of the general acceleration of metabolic processes. The increased acetylation after the administration of acetate points to a lack of available acetyl groups in this disease. It is unlikely that this lack is due to its diminished formation, but may well be due to a rapid utilization of the acetate. A lack of coenzyme $\mathrm{A}$ does not seem to be involved since patients $\mathrm{RO}$ and $\mathrm{KO}$ excreted normal amounts of pantothenate at the height of the disease, and acetylation was not significantly altered in one hyperthyroid patient by the administration of pantothenate.

The role of the kidney in acetylation has not been evaluated in this study. In the rat the kidney is not necessary for acetylation, since the data of Beyer and his associates (19) reveal that the amount of the acetylated form of sulfonamides in the blood is as high in nephrectomized as in normal animals. The kidney, however, differentiates between the free and acetylated form of these compounds, clearing the acetylated form more rapidly.

\section{SUMMARY}

1. The capacity to acetylate PABA and sulfadiazine was studied in normal subjects and in patients with various metabolic diseases. As the dose of PABA was increased, the per cent acetylated of the amount excreted decreased, although the total amount acetylated increased. Normal subjects given a standard dose of $500 \mathrm{mgm}$. PABA, acetylated $88 \pm 1.9 \%$.

2. In patients with severe liver disease acetylation was normal. It is inferred that acetylation does not occur exclusively or necessarily primarily in the liver, but that other tissues participate in this function and acetylate also.

3. Acetylation was normal in patients with rheumatoid arthritis, diabetes mellitus, hypothyroidism, sprue and leukemia.

4. Patients with hyperthyroidism had a diminished capacity to acetylate. This usually returned to within normal limits as the hyperthyroidism was controlled and at the same time the serum level of cholesterol tended to rise. In two patients with hyperthyroidism the administration of sodium acetate increased the capacity to acetylate. It is suggested that in hyperthyroidism there is a decrease in available acetate due to its rapid utilization which may contribute to the decreased ability to acetylate PABA.

\section{ACKNOWLEDGMENTS}

The authors wish to thank Dr. Elaine P. Ralli for her encouragement and constructive criticism. Thanks are due to Bert Laken, Joan Hegeman and Gordon Hiebert for technical assistance.

The PABA was supplied by the International Vitamin Corporation of New York, calcium pantothenate by the Lederle Laboratories, and Panthenol by Hoffmann-La Roche, Inc. PABA for intravenous use was supplied by Wyeth Inc.

\section{BIBLIOGRAPHY}

1. Bloch, K., The metabolism of acetic acid in animal tissues. Physiol. Rev., 1947, 27, 574.

2. Bloch, K., and Rittenberg, D., On the utilization of acetic acid for cholesterol formation. J. Biol. Chem., 1942, 145, 625.

3. Bloch, K., and Rittenberg, D., An estimation of acetic acid formation in the rat. J. Biol. Chem., 1945, 159, 45.

4. Rittenberg, D., and Bloch, K., The utilization of acetic acid for fatty acid synthesis. J. Biol. Chem., 1944, $154,311$.

5. Lorber, V., Lifson, N., and Wood, H. G., Incorporation of acetate carbon into rat liver glycogen by pathways other than carbon dioxide fixation. J. Biol. Chem., 1945, 161, 411.

6. Lipmann, F., Kaplan, N. O., Novelli, G. D., Tuttle, L. C., and Guirard, B. M., Coenzyme for acetylation, a pantothenic acid derivative. J. Biol. Chem., $1947,167,869$.

7. Lipmann, F., Acetylation of sulfanilamide by liver homogenates and extracts. J. Biol. Chem., 1945, 160, 173.

8. Bratton, A. C., and Marshall, E. K., Jr., A new coupling component for sulfanilamide determination. J. Biol. Chem., 1939, 128, 537.

9. Clarke, D. H., and Marney, A. F., The determination of the free and total cholesterol of plasma with the photoelectric colorimeter. J. Lab. \& Clin. Med., 1945, 30, 615.

10. Howe, P. E., The determination of proteins in the blood; a micro-method. J. Biol. Chem., 1921, 49, 109.

11. Quick, A. J., The clinical application of the hippuric acid and the prothrombin tests. Am. J. Clin. Path., 1940, 10, 222. 
12. Charalompous, F. C., and Hegsted, D. M., Acetylation in the diabetic rat. J. Biol. Chem., 1949, 180, 623.

13. Riggs, T. R., and Hegsted, D. M., Some factors affecting the acetylation of $p$-aminobenzoic acid in the rat. J. Biol. Chem., 1949, 178, 669.

14. Riggs, T. R., and Hegsted, D. M., The effect of pantothenic acid deficiency on acetylation in rats. J. Biol. Chem., 1948, 172, 539.

15. Srere, P. A., Chaikoff, I. L., and Dauben, W. G., The in vitro synthesis of cholesterol from acetate by surviving adrenal cortical tissue. J. Biol. Chem., 1948, 176, 829.
16. Srere, P. A., Chaikoff, I. L., Treitman, S. S., and Burstein, L. S., The extrahepatic synthesis of cholesterol. J. Biol. Chem., 1950, 182, 629.

17. Bloch, K., Borek, E., and Rittenberg, D., Synthesis of cholesterol in surviving liver. J. Biol. Chem., 1946, 162, 441.

18. Kaplan, N. O., and Lipmann, F., The assay and distribution of coenzyme A. J. Biol. Chem., 1948, 174, 37.

19. Beyer, K. H., Russo, H. F. Patch, E. A., Peters, L., and Sprague, K. L., The formation and excretion of acetylated sulfonamides. J. Lab. \& Clin. Med., 1946, 31, 65. 